\title{
Leaf area estimation in some species of fruit tree by using models as a non-destructive method
}

\author{
Hüsnü DEMIRSOY*
}

Ondokuz Mayis Univ., Fac. Agric., Dep. Hortic.,

55139-Kurupelit, Samsun, Turkey

husnud@omu.edu.tr
${ }^{*}$ Correspondence and reprints

Fruits, 2009, vol. 64, p. $45-51$ (C) 2009 Cirad/EDP Sciences All rights reserved DOI: $10.1051 /$ fruits:2008049 www.fruits-journal.org

RESUMEN ESPAÑOL, p. 51

\section{Leaf area estimation in some species of fruit tree by using models as a non- destructive method.}

Abstract - Introduction. Leaf area measurements are used commonly in the study of growth and development of fruit trees. These measurements can be made destructively by using a variety of sensitive instruments and/or non-destructively by using models of leaf area estimation. For models of leaf area estimation, some leaf parameters such as the length and width of leaves are usually used in the measurements. Construction of a model of leaf area estimation. Computer programs such as Excel, SAS and SPSS may be used in this process. In brief, after a leaf has been placed on a sheet of paper and photocopied, a digital planimeter or suitable tool may be used to measure the actual leaf area. The leaf width (W) and length (L) of the leaves sampled can be measured by a simple ruler. After this, regression analysis of the data may be performed separately for each genotype, species or cultivar. The analysis can be conducted with various subsets of the independent variables; for instance, leaf length (L), leaf width (W), $\mathrm{L}^{2}, \mathrm{~W}^{2}$ and $\left[\mathrm{L}^{2} / \mathrm{W}^{2}\right]$ to develop the best model for predicting leaf area. Regression analyses should be carried out until the deviation sum of squares is minimized. Models of leaf area estimation for specific crops. In our study, prediction models of leaf area were developed by referring to the relevant current literature that studied such fruits as avocado, banana, blackberry, cacao, cherry, chestnut, grape, guava, kiwifruit, lotus plum, peach, pistachio, rabbiteye blueberry, red currant, red raspberry, sour orange, strawberry, pecan and white mulberry. Advantages and disadvantage of the models of leaf area estimation. Some advantages and a disadvantage of models of leaf area estimation are presented. Conclusion. Our mini-review has shown that the models which have been formulated and which will develop in the future for some fruit species can be reliably used.

Turkey / fruit-growing / models / forecasting / leaf area / methods / measurement / evaluation

\section{Évaluation non destructive de la surface foliaire de certaines espèces fruitières à l'aide de modèles.}

Résumé - Introduction. Des mesures de la surface foliaire sont généralement utilisées pour étudier la croissance et le développement des arbres fruitiers. Ces mesures peuvent utiliser des instruments de précision et être destructives et/ou utiliser des modèles permettant l'évaluation de la surface foliaire et être non destructives. Pour ce type de modèle, certains paramètres de la feuille comme la longueur et la largeur des feuilles sont habituellement considérés. Construction d'un modèle d'évaluation de la surface foliaire. Des programmes informatiques tels qu'Excel, SAS ou SPSS peuvent être utilisés dans ce contexte. Brièvement, après qu'une feuille ait été placée sur du papier et photocopiée, un planimètre numérique ou un autre outil approprié peut être utilisé pour mesurer la surface réelle de la feuille. La largeur de feuille (L) et la longueur (l) des feuilles échantillonnées peuvent être mesurées par une simple règle. Ensuite, une analyse de régression des données peut être effectuée indépendamment pour chaque génotype, espèce ou cultivar. L'analyse peut être conduite avec divers sous-ensembles de variables indépendantes, par exemple, la largeur de feuille (L), la longueur de feuille (l), $\mathrm{L}^{2}, 1^{2}$ et $\left[1^{2} / \mathrm{L}^{2}\right]$ pour développer le meilleur modèle possible pour la prévision de la surface foliaire. Des analyses de régression doivent être menées jusqu'à ce que la somme des carrés des écarts soit réduite au minimum. Modèles d'évaluation de la surface foliaire, spécifiques à certaines cultures. Dans notre étude, nous avons présenté des modèles de prévision de la surface foliaire en se référant à la littérature en cours traitant de fruits tels que l'avocat, la banane, la mûre, le cacao, la cerise, la châtaigne, le raisin, la goyave, le kiwi, la prune, la pêche, la pistache, l'airelle, la groseille, la framboise, l'orange amère, la fraise, la noix de pécan et la mûre blanche. Avantages et inconvénient des modèles d'évaluation de la surface foliaire. Quelques avantages et un inconvénient des modèles d'évaluation de la surface foliaire sont présentés. Conclusion. Notre revue montre que les modèles qui ont été formulés et qui seront développés à l'avenir pour certaines espèces fruitières peuvent être utilisés avec sureté.

Turquie / culture fruitière / modèle / technique de prévision / surface foliaire / méthode / mesure / évaluation 


\section{Introduction}

Leaf area is commonly evaluated in fruit physiology experiments. Determination of leaf area is an important criterion in understanding respiration, transpiration, photosynthesis, light interception, water and nutrient use, flowering, fruit set, crop growth, yield, and quality [1-20]. In addition, estimation of leaf number and whole plant leaf area are important in terms of cultural practices such as pruning, irrigation, fertilization, etc. Leaf area is also needed for assessments of vine $[4,21]$ and fruit growth, evaluation of training and pruning systems, and estimation of pest population densities [19-23].

Leaf area can be determined by using either instruments or prediction models. A large number of methods, either destructive or not, have been developed to measure leaf area. Destructive methods, including tracing, blueprinting, photographing, or using a conventional planimeter, require the excision of leaves from the plants. Therefore, it is impossible to make successive measurements of the same leaf. Also, the plant canopy is damaged, which might affect other measurements or experiments [24]. Non-destructive methods, which do not require the leaves to be detached, are useful because they allow measurements to be repeated during the plant's growth period, and reduce the variability associated with destructive sampling procedures [25]. Recently, new instruments and laser optic apparatuses have been developed for some leaf area measurements [26-33]. However, some of these devices are somewhat expensive, time-consuming and complex [34, 35 ] for basic and simple studies. Some studies [36-39] mention that there are relatively inexpensive hand scanners and some digital imaging techniques available to measure the leaf area.

\section{Construction of a model of leaf area estimation}

In general, the development of an estimation model of leaf area requires the meas- urement of the actual area of each leaf and, often, multiple regressions with length and /or width, etc. Common parameters for prediction equations are leaf length, leaf width, petiole length, or some combination of these variables [40].

Many studies have been carried out with linear leaf measurements that are highly correlated with leaf area in fruit trees such as grapevine [21, 41], apple [42], pear [42, 43], peach [44], strawberry [45], apricot [43] and cherry [46]. Computer programs such as Excel, SAS and SPSS may be used in this process. For example, for a typical method, each leaf should be placed on a sheet of paper and be photocopied. Then, to measure the actual leaf area, a digital planimeter or suitable tool may be used. The leaf width (W) and length (L) of the leaves sampled can be measured by a simple ruler. After this, regression analysis of the data may be performed separately for each genotype, species or cultivar. The analysis can be conducted with various subsets of the independent variables; for instance, leaf length, leaf width, 'leaf length', $\left(\mathrm{L}^{2}\right)$, 'leaf width', $\left(\mathrm{W}^{2}\right)$ and the $\left[\mathrm{L}^{2} / \mathrm{W}^{2}\right]$ ratio to develop the best model for predicting leaf area. Regression analyses should be carried out until the deviation sum of squares is minimized.

To choose the best model, standard error, coefficient of correlation $\left(R^{2}\right)$, probability and $\mathrm{F}$ values of the proposed model are considered. In addition, representative leaf samples should be used to increase reliability of the model.

Samples consisting of leaves of different sizes should be used to produce an accurate leaf area estimation equation. Otherwise, the equation will probably be unreliable. For example, when we produced an estimation model for the peach [44], we saw that our equation yielded a mistaken result for small leaves; after we reconstructed our model by examining more smaller leaves, accuracy of the model increased [44]. As measurement of the leaf area of plants such as grapevine is more complicated than for plants such as the peach tree, more samples are therefore required to produce an accurate model. Ackley et al. [47] also noted calculations of the minimum number of leaves to provide a reliable linear measurement to 
area conversion modeling equation. So, any proposed model should be validated with independent data before being used for experiments.

The use of a validated estimation model of leaf area is straightforward and saves time. However, developing a new leaf area model can be time-consuming, lasting for up to three months. For example, a large number of leaf samples of varying sizes can be collected, either from an orchard at different periods or, when leaves reach the desired size, from an orchard at one time.

\section{Leaf area estimation models for specific fruit crops}

Several leaf area prediction models have been produced in previous studies for fruit species such as avocado [48], banana [8], blackberry [48], cacao [49], cherry [46, 50, 51], chestnut [52], grape [22, 48, 53], guava [17], kiwifruit [54], lotus plum [48], peach [44], pistachio [55], rabbiteye blueberry [56], red currant [48], red raspberry [48], sour orange [18], strawberry [45, 57], pecan [16] and white mulberry [58] (table I).

\section{Advantages and disadvantage of the estimation models of leaf area}

Models to predict leaf area non-destructively can provide researchers with many advantages in horticultural experiments. The most important advantages are as follows:

1. The models enable researchers to measure leaf area on the same plants during plant growth. The equations allow estimations of leaf growth from bud burst to leaf fall, and they reduce variability since the same leaf is used during the experiment. In addition, destructive leaf area measurements are not possible in many investigations. The use of equations eliminates the need for the detachment of leaves from plants.

2. Reliable models eliminate the need for expensive leaf area meters and labor.
3. Leaf area measurement is easy and quick if a reliable equation is obtained or chosen, thereby saving time.

4. In leaf measurements, consistent results are obtained by reliable equations, although non-consistent results may be obtained by a planimeter, depending upon hand manipulation.

5. Use of the modeling equations costs nothing.

In addition, Reynolds [49] suggested that, in nutritional studies of young cacao cuttings, it became necessary to develop a rapid method for estimating leaf area. Ramkhelawan and Brathwaite [18] stated that, in weed control investigations involving container-grown sour orange rootstocks, it became necessary to estimate leaf area by a non-destructive method. Kobayashi [17] indicated that a rapid non-destructive method for estimating the leaf area of the guava in the field would be useful.

A considerable disadvantage of non-destructive methods is that, if the equation is unreliable, incorrect results may be obtained. To prevent this, leaf samples must be taken at different times and chosen at different sizes while an equation of the leaf area estimation is constructed. In addition, the equation should be tested or evaluated for each leaf at different sizes. Moreover, the obtained equation must be validated by other leaf samples before it is used in any experiment.

\section{Conclusion}

Nowadays, computer technology and mathematical modeling are progressing rapidly. These, and other developments, have advanced well. The developments have facilitated and accelerated our scientific studies. Therefore, benefiting from the opportunities is useful and necessary. This study is a mini-review that presents some leaf area estimation models with information regarding the advantages and disadvantage of their usage. Moreover, it gives suggestions about how an accurate mathematical model may be constructed. Most importantly, this mini-review shows 
Table I.

The leaf area estimation models of some fruit species [LA: leaf area $\left(\mathrm{cm}^{2}\right), \mathrm{W}$ : leaf width $(\mathrm{cm}), \mathrm{L}$ : leaf length (cm)]. Validation means comparison of actual and predicted leaf area values.

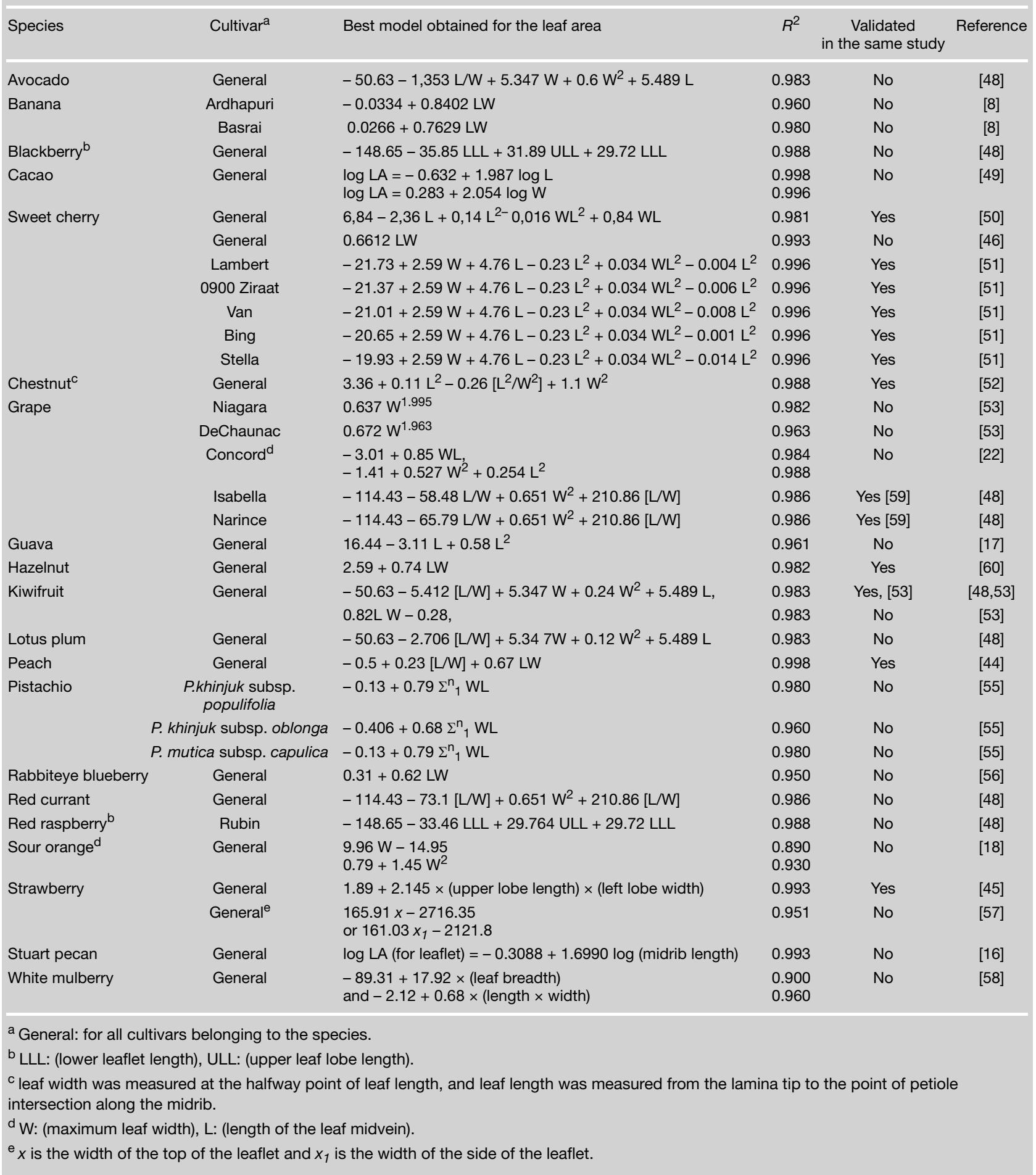


that the models produced in previous studies for fruit species can be reliably used.

\section{Acknowledgement}

I would like to thank Prof. Gregory A. Lang for editing this paper.

\section{References}

[1] Smart R.E., Photosynthesis by grapevine canopies, J. Appl. Ecol. 11 (1974) 997-1006.

[2] Barlow H.W.B., The relationship between leaf size and shoot length in apple, Hortic. Sci. 55 (1980) 279-283.

[3] Hughes B.R., Proctor J.T.A., Estimation of leaflet, leaf and total leaf area of Panax quinquefolius L. using linear measurements, $\mathrm{J}$. Am. Soc. Hortic. Sci. 106 (1981) 167-170.

[4] Smith R.J., Kliewer W.M., Estimation of Thompson seedless grapevine leaf area, Am. J. Enol. Vitic. 35 (1984) 16-22.

[5] Smart R.E., Principles of grapevine canopy microclimate manipulation with implications for yield and quality: a review, Am. J. Enol. Vitic. 36 (1985) 230-239.

[6] Williams L.E., Growth of 'Thompson seedless' grapevines. I. Leaf area development and dry weight distribution, J. Am. Soc. Hortic. Sci. 112 (1987) 325-330.

[7] Kalina J., Slovak V., The inexpensive tool for the determination of projected leaf area, Ekol. Bratisl. 23 (2004) 163-167.

[8] Potdar M.V., Pawar K.R., Non-destructive leaf area estimation in banana, Sci. Hortic. 45 (1991) 251-254.

[9] Rieger M., Duemmel M.J., Comparison of drought resistance among Prunus species from divergent habitats, Tree Physiol. 11 (1992) 369-380.

[10] Horsley S.B., Gottschalk K.W., Leaf area and net photosynthesis during development of Prunus serotina seedlings, Tree Physiol. 12 (1) (1993) 55-69.

[11] Gottschalk K.W., Shade, leaf growth and crown development of Quercus rubra, Quercus velutina, Prunus serotina and Acer rubrum seedlings, Tree Physiol. 14 (1994) 735-749.
[12] Kerstiens G., Hawes C.W., Response of growth and carbon allocation to elevated $\mathrm{CO}_{2}$ in young cherry (Prunus avium L.) saplings in relation to root environment, New Phytol. 128 (1994) 607-614.

[13] Picchioni G.A., Weinbaum S.A., Retention and the kinetics of uptake and export of foliage-applied, labelled boron by apple, pear, prune, and sweet cherry leaves, J. Am. Soc. Hortic. Sci. 120 (1995) 28-35.

[14] Uzun S., The quantitative effects of temperature and light environment on the growth, development and yield of tomato (Lycopersicon esculentum Mill.) and aubergine (Solanum melongena L.), Univ. Reading, thesis, UK, 1996, $221 \mathrm{p}$.

[15] Centritto M., Loreto F., Massacci A., Pietrini F., Villani M.C., Zacchine M., Improved growth and water use efficiency of cherry saplings under reduced light intensity, Ecol. Res. 15 (2000) 385-392.

[16] Sparks D., A rapid method for estimating the leaf area of the Stuart pecan, Carya illinoensis Koch., HortSci. 1 (1966) 93-94.

[17] Kobayashi K.D., Estimating leaf area of 'Beaumont' guava, Trop. Agric. 65 (1988) 173-175.

[18] Ramkhelawan E., Brathwaite R.A.I., Leaf area estimation by non destructive methods in sour orange (Citrus aurantium L.), Trop. Agric. 67 (1990) 203-206.

[19] Lang G.A., Underlying principles of highdensity sweet cherry production, Acta Hortic. 667 (2005) 325-335.

[20] Anderson R.L., Robinson T., Lang G.A., Managing the Gisela cherry rootstocks. N.Y., Fruit Quarterly 7 (1999) 19-22.

[21] Sepulveda G.R., Kliewer W.M., Estimation of leaf area of two grapevine cultivars (Vitis vinifera L.) using laminae linear measurements and fresh weight, Am. J. Enol. Vitic. 34 (1983) 221-226.

[22] Elsner E.A., Jubb G.L., Leaf area estimation of concord grape leaves from simple linear measurements, Am. J. Enol. Vitic. 39 (1988) 95-97.

[23] Lang G.A., Precocious, dwarfing and productive - How will new cherry rootstocks impact the sweet cherry industry? HortTechnol. 10 (2000) 719-725.

[24] Lu H.Y., Lu C.T., Wei M.L., Chan F.L., Comparison of different models for non-destructive leaf area estimation in Taro, Agron. J. 96 (2004) 448-453. 
[25] Silva P.S.L., Barbin D., Gonçalvez R.J.S., Firmino J.D.C., Fonseca I.C., Leaf area estimates of custard apple tree progenies, Rev. Bras. Frutic. 26 (2004) 558-560.

[26] Fladung M., Ritter, E., Plant leaf area measurements by personal computers, J. Agron. Crop Sci. 166 (1991) 69-70.

[27] Mori S., Kawasaki T., Takeuchi L., Nondestructive measurement of the growth of leaf area by means of a portable copying machine, J. Jpn. For. Soc. 73 (1991) 298300.

[28] Smith W.K., Schoettle A.W., Cui M., Importance of the method of leaf area measurement to the interpretation of gas exchange of complex shoots, Tree Physiol. 8 (1991) 121127.

[29] Blanke M., Scanner for leaf area measurement - leaves keep their form, Gartenbaumag. 3 (1995) 27-28.

[30] Ebert G., Leaf area measurement with laser optics, Erwerbsobstbau 37 (1995) 87-188.

[31] Villalobos F.J., Orgaz F., Mateos L., Nondestructive measurement of leaf area in olive (Olea europaea L.) trees using a gap inversion method, Agric. For. Meteorol. 73 (1995) 29-42.

[32] Beverly R.B., van Lersel M.V., Calibration of a video image analysis system for measurement of stem length, leaf area, and percent ground coverage, Commun. Soil Sci. Plant Anal. 29 (1998) 1071-1081.

[33] Igathinathane C., Prakash V.S.S., Padma U., Babu G.R., Womac A.R., Interactive computer software development for leaf area measurement, Comput. Electron. Agric. 51 (2006) $1-16$

[34] Manivel L., Weaver R.J., Biometric correlations between leaf area and length measurements of 'Grenache' grape leaves, HortSci. 9 (1974) 27-28.

[35] Robbins N.S., Pharr D.M., Leaf area prediction models for cucumber from linear measurements, HortSci. 22 (1987) 1264-1266.

[36] Tsonev T., Sergiev I., Leaf-area measurement using hand scanner, Photosynth. 29 (1993) 625-630.

[37] Baker B., Olszyk D.M., Tingey D., Digital image analysis to estimate leaf area, J. Plant. Physiol. 148 (1996) 530-535.

[38] Korva J.T., Forbes G.A., A simple and low cost method for leaf area measurement of detached leaves, Exp. Agric. 33 (1997) 65-72.
[39] O'Neal M.E., Landis D.A., Isaacs R., An inexpensive, accurate method for measuring leaf area and defoliation through digital image analysis, J. Econ. Entomol. 95 (2002) 11901194.

[40] Gamiely S., Randle W.M., Mills H.A., Smittle D.A., A rapid and non-destructive method for estimating leaf area of onions. HortSci. 26 (1991) 206.

[41] Gutierrez T., Lavin A., Linear measurements for non-destructive estimation of leaf area 'Chardonnay' vines, Agric. Tec. 60 (2000) 67-69.

[42] Boyuton D., Harris R.W., Relationship between leaf dimensions, leaf, and shoot length in the Mclntosh apple, Elberta peach, and Italian prune, Proc. Am. Soc. Hortic. Sci. 55 (1950) 16-20.

[43] Kumar K., Srivastava R.P., Singh A.K., Bana D.S., Use of linear measurement in the estimation of leaf area of some apricot, peach, plum, pear and guava varieties, Indian J. Hortic. 34 (1977) 229-234.

[44] Demirsoy H., Demirsoy L., Uzun S., Ersoy B., Non-destructive leaf area estimation in peach, Eur. J. Hortic. Sci. 69 (2004) 144-146.

[45] Demirsoy H., Demirsoy L., Ozturk A., Improved model for the non-destructive estimation of strawberry leaf area, Fruits 60 (2005) 69-73.

[46] Cittadini E.D., Peri L., Estimation of leaf area in sweet cherry using a non-destructive method, RIA (INTA) 35 (2006) 143-150.

[47] Ackley W.B., Crandall P.C., Russell T.S., The use of linear measurements in estimating leaf areas, Proc. Am. Soc. Hortic. Sci. 72 (1958) 326-330.

[48] Uzun S., Çelik H., Leaf area prediction models (uzçelik-1) for different horticultural plants, Turk. J. Agric. For. 23 (1999) 645-650.

[49] Reynolds S.G.A., A note on estimation of leaf areas of Cacao (Theobroma cacao L.) from three leaf parameters, Trop. Agric. 48 (1971) 177-179.

[50] Demirsoy L., Demirsoy H., Leaf area estimation model for some local cherry genotypes in Turkey, Pak. J. Biol. Sci. 6 (2003) 153-156.

[51] Demirsoy H., Demirsoy L., A validated leaf area prediction model for some cherry cultivars in Turkey, Pak. J. Bot. 35 (2003) 361367. 
[52] Serdar U., Demirsoy H., Non-destructive leaf area estimation in chestnut, Scientia Hortic. 108 (2006) 227-230.

[53] Williams L., Martinson T.E., Non-destructive leaf area estimation of 'Niagara' and 'De Chaunac' grapevines, Scientia Hortic. 98 (2003) 493-498.

[54] Mendoza-De Gyves E., Rouphael Y., Cristofori V., Mira F.R., A non-destructive, simple and accurate model for estimating the individual leaf area of kiwi (Actinidia deliciosa), Fruits 62 (2007) 171-176.

[55] Ranjbar A., Damme P. van, Estimation of leaf area by non-destructive methods in three Iranian pistachio species (Pistacia mutica subsp. cabulica, Pistacia khinjuk subsp. oblonda and Pistacia khinjuk subsp. populifolia), Mededelingen - Fac. Landbouwkd. Toegep. Biol. Wet. Univ. Gent 64 (2) (1999) 49-56.
[56] Nesmith D.S., Non-destructive leaf area estimation of rabbiteye blueberries, HortSci. 26 (1991) 132.

[57] Mandal K.K., Ghosh S.K., Gayen P., A nondestructive way of leaf area estimation in the strawberry, Ann. Biol. 18 (2002) 19-24.

[58] Satpathy B., Shivnath A., Rao K.M., Ghosh P.L., Nair B.P., An easy and rapid method of leaf area estimation in white mulberry (Morus alba), Indian J. Agric. Sci. 62 (1992) 489-491.

[59] Celik H., Uzun S., Validation of leaf area estimation models (Uzçelik-1) evaluated for some horticultural plants, Pak. J. Bot. 34 (2002) 41-46.

[60] Cristofori V., Rouphael Y., Mendoza-de Gyves E., Bignami, C., A simple model for estimating leaf area of hazelnut from linear measurements, Scientia Hortic. 113 (2007) 221-225.

\section{Evaluación no destructiva de la superficie foliar de ciertas especies fruteras con la ayuda de modelos.}

Resumen - Introducción. Con el fin de estudiar el crecimiento y el desarrollo de árboles frutales se emplean generalmente medidas de la superficie foliar. Dichas medidas pueden emplear instrumentos de precisión y ser destructivas y/o emplear modelos que permitan la evaluación de la superficie foliar y ser de este modo no destructivas. Para este tipo de modelos se consideran habitualmente ciertos parámetros de la hoja como la longitud y la anchura de las hojas. Construcción de un modelo de evaluación de la superficie foliar. Se pueden emplear en este contexto programas informáticos como por ejemplo Excel, SAS o SPSS. En pocas palabras, después de que la hoja se haya colocado encima de papel y se haya fotocopiado se puede emplear un planímetro numérico u otro instrumento apropiado para medir la superficie real de la hoja. La anchura de la hoja (L) y la longitud (1) de las hojas muestreadas pueden medirse con una regla convencional. Seguidamente se puede llevar a cabo independientemente un análisis de regresión de los datos para cada genotipo, especie o cultivar. Se puede efectuar el análisis con diversos sub-conjuntos de variables independientes, por ejemplo, la anchura de la hoja (L), la longitud de hoja (l), $\mathrm{L}^{2}, \mathrm{l}^{2}$ y $\left[\mathrm{l}^{2} / \mathrm{L}^{2}\right]$ para desarrollar así el mejor modelo posible para la previsión de la superficie foliar. Se deben ejecutar análisis de regresión hasta que la suma de los cuadrados de las separaciones se reduzca al mínimo. Modelos de evaluación de la superficie foliar, específicos a ciertos cultivos. En nuestro estudio, presentamos modelos de previsión de la superficie foliar con referencia a la literatura en curso que trata de frutos como el aguacate, el plátano, la mora, el cacao, la cereza, la castaña, el arándano, la grosella, la frambuesa, la naranja amarga, la fresa, la pecana, y la mora blanca. Ventajas e inconveniente de los modelos de evaluación de la superficie foliar. Se presentaron ciertas ventajas y un inconveniente de los modelos de evaluación de la superficie foliar. Conclusión. Nuestro informe muestra que se pueden utilizar con seguridad los modelos que se formularon y que se desarrollarán en el futuro para ciertas especies fruteras.

Turquía / fruticultura / modelos / técnicas de predicción / superficie foliar / métodos / medicon / evaluación 